\title{
Supporting evidence varies for rangeland management practices that seek to improve soil properties and forage production in California
}

The authors synthesized the effects of silvopasture, grazing, compost application and riparian restoration on soil properties and forage production.

by Chelsea J. Carey, Kelly Gravuer, Sasha Gennet, Dillon Osleger and Stephen A. Wood

Online: https://doi.org/10.3733/ca.2020a0015

$\mathrm{R}$ angelands make up approximately 57 million acres of California's land area, with Mediterranean-type grasslands, shrublands and woodlands accounting for $30 \%$ of this estimate (FRAP 2018). The predominant economic use of California's rangelands is forage production, which supports a $\$ 2.6$ billion cattle industry (CDFA 2018). These landscapes are also globally recognized as hot spots of biological diversity (Myers et al. 2000), and they provide an array of ecosystem services beyond food production, including water and nutrient cycling (Byrd et al. 2015), pollination (Chaplin-Kramer et al. 2011), carbon storage for climate change mitigation (Dass et al. 2018), and recreational opportunities (Plieninger et al. 2012).

As the land area of California's rangelands continues to shrink due to dramatic population growth and concomitant cropland and urban expansion (Cameron et al. 2014), societal demands from each acre are increasing. Private ranchers and public rangeland managers now desire, or are expected, to predictably optimize production of the full array of values and

\section{Abstract}

California is increasingly investing in policies and programs that promote soil stewardship on natural and working lands as a way to help achieve multiple goals, including improved forage production and climate change mitigation. To inform the growing expectations for rangeland management activities to promote such services, we conducted an evidence synthesis assessing how four commonly suggested practices (silvopasture, prescribed grazing, compost application and riparian restoration) affect a suite of soil properties and plant-related metrics throughout the state. We extracted data on soil properties that are potentially responsive to management and relevant to soil health. We also extracted data on aboveground forage production, forage nitrogen content and herbaceous species richness. Our search resulted in 399 individual soil observations and 64 individual plant observations. We found that the presence of oaks had the largest effects on soil properties, with soil organic carbon, microbial biomass and other measures of soil fertility increasing beneath oak canopies. The presence of grazing increased compaction and total nitrogen, and decreased pH. Compost applications did not significantly affect any of the measured soil properties, but did boost forage production. Due to a lack of published data, we were unable to characterize the influence of rangeland riparian restoration on any of the soil or plant metrics in our review.

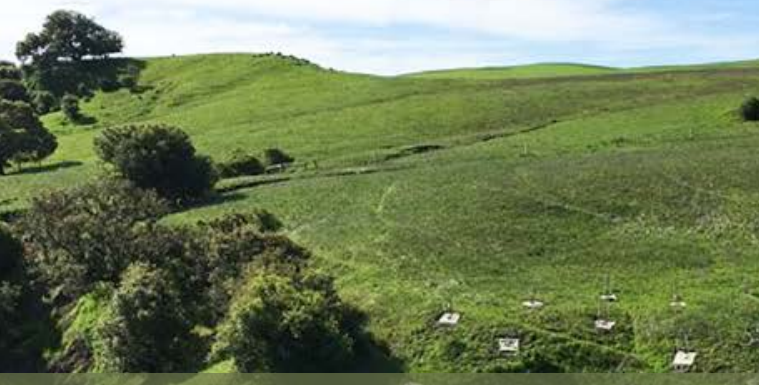

Over 3 miles of riparian area at Tolay Lake Regional Park Petaluma, California, that have been actively restored by Point Blue Conservation Science's Students and Teachers Restoring a Watershed (STRAW) program. The white squares are plants installed by volunteers, including coast live oak, buckeye, coffeeberry, California rose and more.
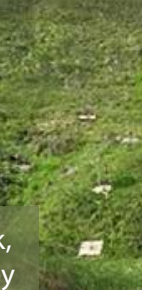
3. 4

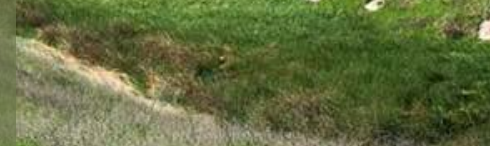

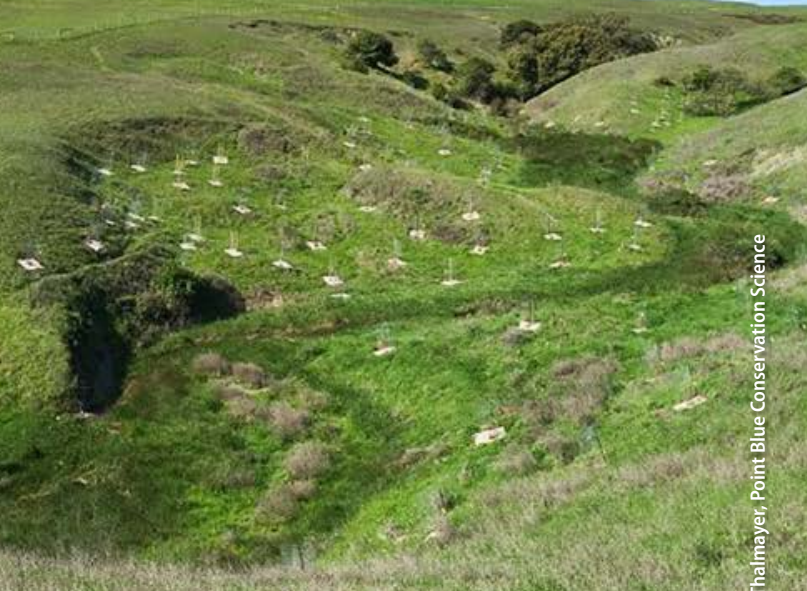


services (Boyd and Svejcar 2009; Ferranto et al. 2014; Plieninger et al. 2012) in a way that promotes ecosystem resilience and adaptation to global and regional pressures (Hruska et al. 2017; Sayre et al. 2012).

Soils are receiving increased attention within the scientific discourse on rangeland management because of their role in supporting ecosystem services like forage production and, in some cases, climate change mitigation (Byrnes et al. 2018; Derner et al. 2016; Derner et al. 2018). In California, as elsewhere, this recognition is making its way into the public sphere, influencing both policy and practice (Bradford et al. 2019; Byrnes et al. 2017).

Indeed, a 2011 survey of California ranchers identified that maintaining or improving soil "health" was, on average, a midpriority goal that ranked similarly to managing weeds and water quality (Roche et al. 2015). Although the same survey revealed that managing soils to promote carbon sequestration was not an important goal for ranchers (Roche et al. 2015), since 2011 there have been several new policies and incentive programs put in place to promote carbon sequestration on rangelands. For example, rangeland soil management is now named by the California 2030 Natural and Working Lands Climate Change Implementation Plan as a critical climate change mitigation strategy, and policy and funding through the California Department of Food and Agriculture's Healthy Soils Program aim to maximize this outcome.

The growing expectation for range management activities to promote on-site (e.g., forage production) and public (e.g., carbon sequestration) ecosystem services demands a quantitative synthesis of the literature summarizing whether, and to what degree, desired outcomes have been shown to be achievable by implementing these activities. To that end, we synthesized the documented effects of four commonly prescribed rangeland management practices on a suite of soil properties and plant-related metrics in California. These management practices, which are currently incentivized by the Healthy Soils Program, are silvopasture establishment (USDA NRCS 2016, 381), prescribed grazing (USDA NRCS 2016, 528), compost application, and riparian restoration (USDA NRCS 2016, 391).

Previous work indicates that these practices have the potential to influence plant dynamics and increase soil organic carbon (hereafter soil C) in some rangeland ecosystems (Byrnes et al. 2018; Dybala, Matzek, et al. 2019; Gravuer et al. 2019) — and there is reason to believe they can also affect other soil properties, such as soil compaction and nitrogen $(\mathrm{N})$ availability (Byrnes et al. 2018; Dahlgren et al. 1997; Zhou et al. 2017). In California's arid and semiarid Mediterranean climate, however, the effects of rangeland management may be overwhelmed by strong interannual variability in precipitation (Jackson and Bartolome 2007), spatial variability in soil type and topography (Booker et al. 2013; Graham and O'Geen 2016) and land-use history (Huntsinger et al. 2007).
This variability results in mixed evidence for California rangelands to respond to management practices and generates risks associated with extrapolating results from single studies or from other, perhaps more malleable, mesic regions (Allen-Diaz and Jackson 2005). Our targeted search and synthesis of California's literature at least partially addresses these risks, and supplements ongoing work in the state that is providing scientific underpinnings for an expanding rangeland management framework.

\section{Literature review and synthesis}

We performed a subject-wide evidence synthesis on data derived exclusively from California rangelands. A subject-wide evidence synthesis is a way to review and summarize the effects of multiple practices or interventions simultaneously using some combination of qualitative and quantitative methods, and it can be a cost-effective approach to support management and policy decision making (Shackelford et al. 2019). In our synthesis, we extracted soil and plant data from relevant studies that fulfilled specific requirements and aggregated similar response metrics into umbrella categories (e.g., the cations category combines values of individual exchangeable cations, base saturation and cation exchange capacity).

For composite metric-management pairs that had soil observations across at least three sites, we assessed the overall influence of management practices on each metric using random effects meta-analysis modeling, with log response ratios as the effect size (Hedges et al. 1999). For composite plant metrics, we took the same approach but relaxed the criteria to two (rather than three) sites so we could include the effects of compost amendments. Where possible, we also broke apart the composite categories to look at the effect of management practices on contributing variables (on individual exchangeable cations, base saturation, etc.) and explored whether soil texture and aridity moderated the response of metrics to management across studies.

Because we were interested in documenting published evidence in addition to identifying gaps for metric-management pairs regardless of their potential to be included in a formal meta-analysis, we retained all management practices regardless of their support in the literature and qualitatively described our findings in those cases where evidence was limited. See the technical appendix online for more details.

\section{Levels of evidence: Highly variable across management practices}

Our literature review resulted in 399 individual soil observations compiled from 37 publications, reports or unpublished data sets, and 64 individual plant community observations from 26 publications (table 1 ; table 2). The resulting data set represented 35 unique study areas located across California's Mediterranean-type 
TABLE 1. Studies included in the literature review

\begin{tabular}{|c|c|c|}
\hline Publication & DOI (or other identifier) & $\begin{array}{l}\text { Treatment } \\
\text { category }\end{array}$ \\
\hline \multicolumn{3}{|l|}{ Soil properties } \\
\hline Callaway et al. 1991 & https://doi.org/10.2307/1941122 & Silvopasture \\
\hline Camping et al. 2002 & PSW-GTR-184 & Silvopasture \\
\hline Dahlgren et al. 1997 & Biogeochemistry 39 & Silvopasture \\
\hline Dahlgren et al. 2003 & https://doi.org/10.3733/ca.v057n02p42 & Silvopasture \\
\hline Eastburn et al. 2017 & https://doi.org/10.1371/journal.pone.0166595 & Silvopasture \\
\hline $\begin{array}{l}\text { Frost and Edinger } \\
1991\end{array}$ & https://doi.org/10.2307/4002959 & Silvopasture \\
\hline Herman et al. 2003 & $\begin{array}{l}\text { https://doi.org/10.1890/1051- } \\
\text { 0761(2003)013[0593:NDIAAG]2.0.CO;2 }\end{array}$ & Silvopasture \\
\hline Jackson et al. 1990 & https://doi.org/10.1016/0167-8809(90)90126-X & Silvopasture \\
\hline $\begin{array}{l}\text { Marañón and } \\
\text { Bartolome } 1994\end{array}$ & Madroño 41 & Silvopasture \\
\hline $\begin{array}{l}\text { Moody and Jones } \\
2000\end{array}$ & $\begin{array}{l}\text { https://doi.org/10.1016/S0929-1393(00)00053- } \\
6\end{array}$ & Silvopasture \\
\hline $\begin{array}{l}\text { Parker and Muller } \\
1982\end{array}$ & The American Midland Naturalist 107(1) & Silvopasture \\
\hline $\begin{array}{l}\text { Perakis and Kellog } \\
2007\end{array}$ & https://doi.org/10.1007/s11258-006-9238-9 & Silvopasture \\
\hline Rice and Nagy 2000 & https://doi.org/10.2307/2656747 & Silvopasture \\
\hline $\begin{array}{l}\text { Stahlheber and } \\
\text { D'Antonio } 2014\end{array}$ & https://doi.org/10.1111/rec.12103 & Silvopasture \\
\hline Tate et al. 2004 & https://doi.org/10.2307/4003867 & Silvopasture \\
\hline $\begin{array}{l}\text { Waldrop and } \\
\text { Firestone 2006a }\end{array}$ & https://doi.org/10.1007/s00248-006-9100-6 & Silvopasture \\
\hline $\begin{array}{l}\text { Waldrop and } \\
\text { Firestone 2006b }\end{array}$ & https://doi.org/10.1007/s00248-006-9103-3 & Silvopasture \\
\hline $\begin{array}{l}\text { Waldrop and } \\
\text { Firestone } 2004\end{array}$ & http://dx.doi.org/10.1007/s00442-003-1419-9 & Silvopasture \\
\hline Camping et al. 2002 & PSW-GTR-184 & Grazing \\
\hline Dahlgren et al. 1997 & Biogeochemistry 39 & Grazing \\
\hline Esch et al. 2013 & https://doi.org/10.1007/s11104-012-1463-5 & Grazing \\
\hline Funk et al. 2015 & https://doi.org/10.1111/rec.12162 & Grazing \\
\hline Gennet et al. 2017 & https://doi.org/10.1371/journal.pone.0176367 & Grazing \\
\hline George et al. 2004 & https://doi.org/10.3733/ca.v058n03p138 & Grazing \\
\hline Hayes and Holl 2003 & $\begin{array}{l}\text { https://doi.org/10.1111/j.1523- } \\
\text { 1739.2003.00281.x }\end{array}$ & Grazing \\
\hline Hayes (unpublished) & Personal communication & Grazing \\
\hline Herman et al. 2003 & $\begin{array}{l}\text { https://doi.org/10.1890/1051- } \\
\text { 0761(2003)013[0593:NDIAAG]2.0.CO;2 }\end{array}$ & Grazing \\
\hline Marty 2015 & https://doi.org/10.1111/rec.12226 & Grazing \\
\hline Oates et al. 2008 & https://doi.org/10.1007/s11273-007-9076-0 & Grazing \\
\hline $\begin{array}{l}\text { Ratliff and Westfall } \\
1971\end{array}$ & PSW-GTR-254 & Grazing \\
\hline Skaer et al. 2013 & $\begin{array}{l}\text { https://doi.org/10.1111/j.1654- } \\
\text { 1103.2012.01460.x }\end{array}$ & Grazing \\
\hline $\begin{array}{l}\text { Steenwerth et al. } \\
2002\end{array}$ & $\begin{array}{l}\text { https://doi.org/10.1016/S0038- } \\
0717(02) 00144-X\end{array}$ & Grazing \\
\hline
\end{tabular}

\begin{tabular}{|c|c|c|}
\hline Publication & DOI (or other identifier) & $\begin{array}{l}\text { Treatment } \\
\text { category }\end{array}$ \\
\hline $\begin{array}{l}\text { Stromberg and } \\
\text { Griffin } 1996\end{array}$ & https://doi.org/10.2307/2269601 & Grazing \\
\hline Tate et al. 2004 & https://doi.org/10.2307/4003867 & Grazing \\
\hline Ryals et al. 2014 & https://doi.org/10.1016/j.soilbio.2013.09.011 & $\begin{array}{l}\text { Compost } \\
\text { amendment }\end{array}$ \\
\hline Silver et al. 2018 & CCCA4-CNRA-2018-002 & $\begin{array}{l}\text { Compost } \\
\text { amendment }\end{array}$ \\
\hline Briar et al. 2012 & https://doi.org/10.1016/j.ejsobi.2011.11.006 & $\begin{array}{l}\text { Riparian } \\
\text { restoration }\end{array}$ \\
\hline \multicolumn{3}{|l|}{ Plant-related metrics } \\
\hline $\begin{array}{l}\text { Bartolome and } \\
\text { McClaran } 1992\end{array}$ & https://doi.org/10.2307/4002536 & Silvopasture \\
\hline Callaway et al. 1991 & https://doi.org/10.2307/1941122 & Silvopasture \\
\hline Eastburn et al. 2017 & https://doi.org/10.1371/journal.pone.0166595 & Silvopasture \\
\hline Femi et al. 2005 & $\begin{array}{l}\text { https://doi.org/10.2111/1551- } \\
\text { 5028(2005)058[0352:TEOLOC]2.0.CO;2 }\end{array}$ & Silvopasture \\
\hline $\begin{array}{l}\text { Frost and McDougald } \\
1989\end{array}$ & Journal of Range Management 42 & Silvopasture \\
\hline Jackson et al. 1990 & https://doi.org/10.1016/0167-8809(90)90126-X & Silvopasture \\
\hline $\begin{array}{l}\text { Marañón and } \\
\text { Bartolome } 1994\end{array}$ & Madroño 41 & Silvopasture \\
\hline $\begin{array}{l}\text { McLaran and } \\
\text { Bartolome } 1989\end{array}$ & Madroño 36 & Silvopasture \\
\hline $\begin{array}{l}\text { Perakis and Kellog } \\
2007\end{array}$ & https://doi.org/10.1007/s11258-006-9238-9 & Silvopasture \\
\hline Ratliff et al. 1991 & Journal of Range Management 44 & Silvopasture \\
\hline Seabloom et al. 2009 & https://doi.org/10.1890/08-0671.1 & Silvopasture \\
\hline DiTomaso et al. 2008 & https://doi.org/10.1614/IPSM-07-031.1 & Grazing \\
\hline Funk et al. 2015 & https://doi.org/10.1111/rec.12162 & Grazing \\
\hline Gornish et al. 2018 & https://doi.org/10.1071/RJ18020 & Grazing \\
\hline Harrison et al. 2003 & $\begin{array}{l}\text { https://doi.org/10.1046/j.1523- } \\
\text { 1739.2003.01633.x }\end{array}$ & Grazing \\
\hline Hayes and Holl 2003 & $\begin{array}{l}\text { https://doi.org/10.1111/j.1523- } \\
\text { 1739.2003.00281.x }\end{array}$ & Grazing \\
\hline Jackson et al. 2006 & https://doi.org/10.1007/s10021-005-0166-7 & Grazing \\
\hline Keeley et al. 2003 & https://doi.org/10.1890/02-5002 & Grazing \\
\hline Marty 2015 & https://doi.org/10.1111/rec.12226 & Grazing \\
\hline $\begin{array}{l}\text { Safford and Harrison } \\
2001\end{array}$ & https://doi.org/10.2307/3061016 & Grazing \\
\hline Skaer et al. 2013 & $\begin{array}{l}\text { https://doi.org/10.1111/j.1654- } \\
\text { 1103.2012.01460.x }\end{array}$ & Grazing \\
\hline $\begin{array}{l}\text { Stromberg and } \\
\text { Griffin } 1996\end{array}$ & https://doi.org/10.2307/2269601 & Grazing \\
\hline Ryals et al. 2016 & https://doi.org/10.1002/ecs2.1270 & $\begin{array}{l}\text { Compost } \\
\text { amendment }\end{array}$ \\
\hline Ryals and Silver 2013 & https://doi.org/10.1890/12-0620.1 & $\begin{array}{l}\text { Compost } \\
\text { amendment }\end{array}$ \\
\hline Briar et al. 2012 & https://doi.org/10.1016/j.ejsobi.2011.11.006 & $\begin{array}{l}\text { Riparian } \\
\text { restoration }\end{array}$ \\
\hline Gornish et al. 2017 & https://doi.org/10.1371/journal.pone.0176338 & $\begin{array}{l}\text { Riparian } \\
\text { restoration }\end{array}$ \\
\hline
\end{tabular}


TABLE 2. Control and treatment scenarios for each management practice, and associated number of studies and unique observations (parentheses) recovered for soil properties and plant-related metrics

\begin{tabular}{|l|l|l|l|l|}
\hline $\begin{array}{l}\text { Management } \\
\text { practice }\end{array}$ & Control & Treatment & $\begin{array}{l}\text { Soil } \\
\text { properties }\end{array}$ & $\begin{array}{l}\text { Plant } \\
\text { metrics }\end{array}$ \\
\hline Silvopasture & $\begin{array}{l}\text { No oak present } \\
\text { (e.g., open } \\
\text { grassland) }\end{array}$ & $\begin{array}{l}\text { Oak present } \\
\text { (e.g., oak } \\
\text { canopy) }\end{array}$ & $18(237)$ & $11(28)$ \\
\hline Grazing & Ungrazed & Grazed & $16(131)$ & $11(22)$ \\
\hline Compost amendment & Unamended & Amended & $2(20)$ & $2(8)$ \\
\hline Riparian restoration & Unrestored & Restored & $1(11)$ & $2(6)$ \\
\hline Total & - & - & $37(399)$ & $26(64)$ \\
\hline
\end{tabular}

A unique observation is delineated by a combination of publication ID, management practice, study area and response variable. grassland, shrubland and woodland systems (fig. 1); eight of these areas were UC reserves or other research stations, from which $71 \%$ and $50 \%$ of the soil and plantrelated data sets were derived, respectively. Oak presence had the greatest number of soil observations (59\% of the compiled data set), followed by grazing (33\%), compost additions (5\%) and riparian restoration (3\%). This pattern held for plant metrics as well, with $44 \%$, $34 \%, 13 \%$ and $9 \%$ of the observations associated with oak presence, grazing, compost additions and riparian restoration, respectively.

Across all studies, the number of unique observations per metric varied from one to 93 (fig. 2), with soil $\mathrm{N}$ being the most frequently measured parameter, followed by cation availability and soil C content. Only 12 studies presented both soil and plant-related metrics, limiting our ability to draw direct relationships between the response of soil properties and plant dynamics to management intervention.

\section{Silvopasture: Oaks enhance soil fertility}

Silvopasture is an ancient practice that has been implemented in many regions around the world and is recognized for its potential to optimize economic and ecological production while building resilience into some work-

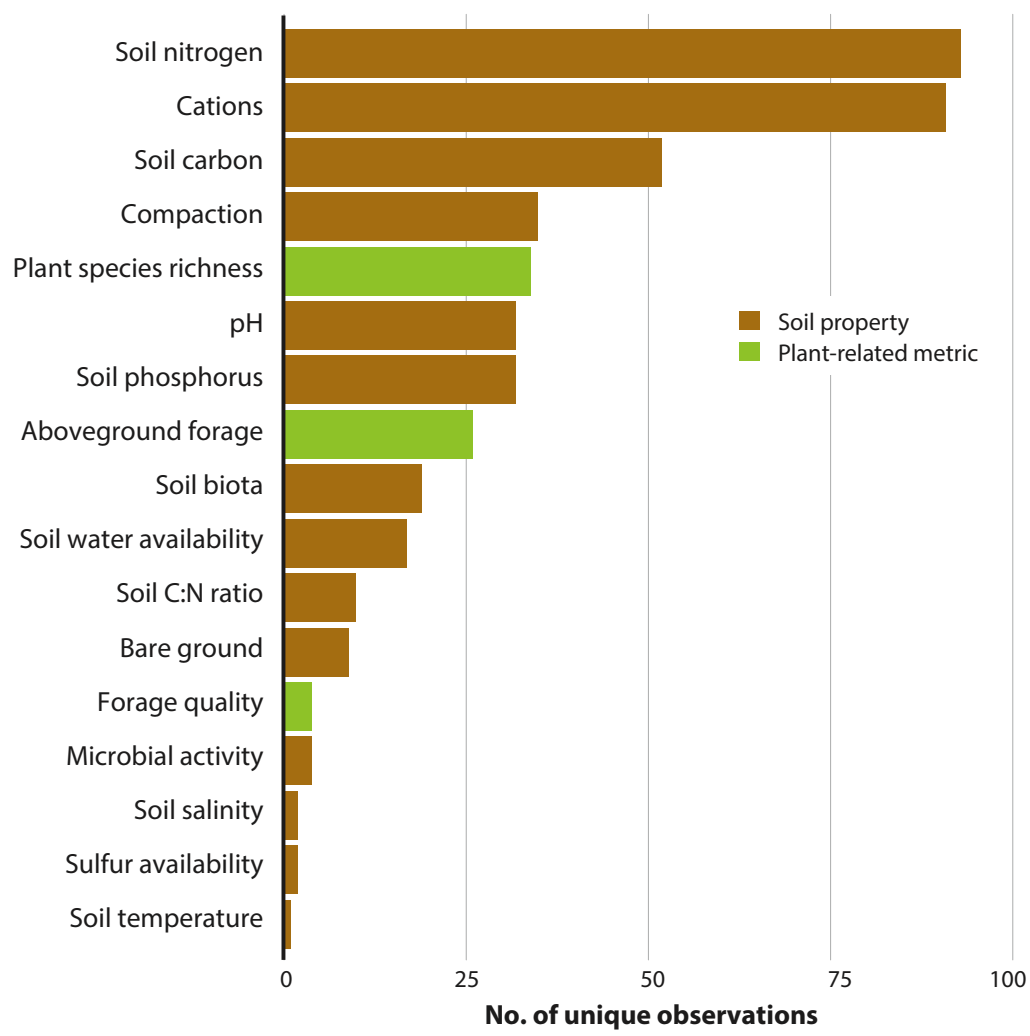

FIG. 2. The number of unique observations representing each soil property and plantrelated metric recovered from the literature. ing landscapes (Jose and Dollinger 2019). The Natural Resources Conservation Service defines silvopasture as the establishment or management of desired trees and forages with the purpose of providing improved forage production, shelter for livestock, soil quality and carbon sequestration, biological diversity and reduced erosion (USDA NRCS 2016).

In California's published literature, silvopasture establishment on rangelands is best represented by work on oak trees (Quercus spp.). And while oaks were historically clear-cut with the intention of maximizing forage production in California (a foundational assumption that was later challenged) (Huntsinger and Fortmann 1990), hardwood rangeland landowners increasingly value and manage for oaks, and the state is striving to increase the pace and scale of oak stewardship by tripling funding for oak savanna reforestation by 2030 (CNWL CCIP 2019; Huntsinger et al. 2010). As such, we focused specifically on assessing the effects of oak presence on soil properties and plant-related metrics in our review, and we included oak removal studies in addition to observational studies measuring conditions under oaks versus in nearby open grasslands.

We found the presence of oaks had the largest effects on soil properties of any of the management practices assessed. When the data were pooled across all studies and contexts, soils beneath oak canopies were more fertile (higher levels of soil phosphorus [P], soil N 
and cation availability), had greater amounts of soil C and microbial biomass, were less compacted and contained more soil moisture than nearby open grasslands (fig. 3). The effects of oaks on soil $\mathrm{N}$ were reflected in both the total $\mathrm{N}$ and plant-available $\mathrm{N}$ pools, and the effects on cations were largely driven by increases in exchangeable potassium, magnesium and calcium (fig. 4).

When accounting for environmental context, we found that soil texture moderated the effect of oaks on soil $\mathrm{C}$ such that the increase beneath oaks was amplified in soils with higher clay content (fig. 5). The effect of oaks on soil P was also greatest in finer-textured soils, and in less arid sites (data not shown). This context dependency aligns with expectations from theory and practice (Booker et al. 2013; Byrnes et al. 2018), suggesting that silvopasture-induced gains in soil C and some metrics of soil fertility, while still apparent, may be muted in sandy soils and hotter, drier areas.

While it is possible that oaks preferentially establish on sites that are inherently more fertile, rapid declines in soil fertility have been observed following the removal of oaks, indicating that the trees create rather than respond to these conditions (Dahlgren et

FIG. 4. Mean response ratio (InRR) and 95\% confidence intervals (CI) for the response of soil $\mathrm{N}$ availability and individual cation metrics to oaks and the presence of grazing. If a metric has $\ln R R>0$ and a $95 \% \mathrm{Cl}$ that does not overlap zero, it significantly increased in the presence of oaks or grazing. The size of each circle is a function of the number of unique observations supporting that relationship.

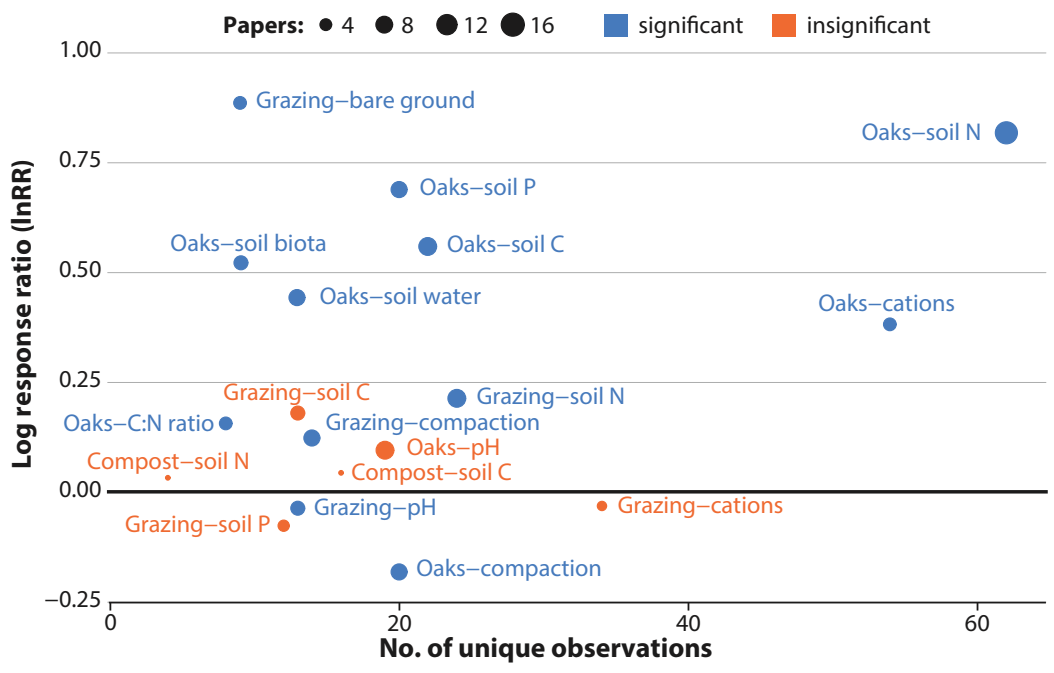

FIG. 3. Mean response ratio (InRR), number of unique observations and significance of management-soil property relationships. Significant difference between treatment and control for a given soil property is denoted by color, with blue points significant and red points insignificant. The size of each circle is a function of the number of papers supporting that relationship.

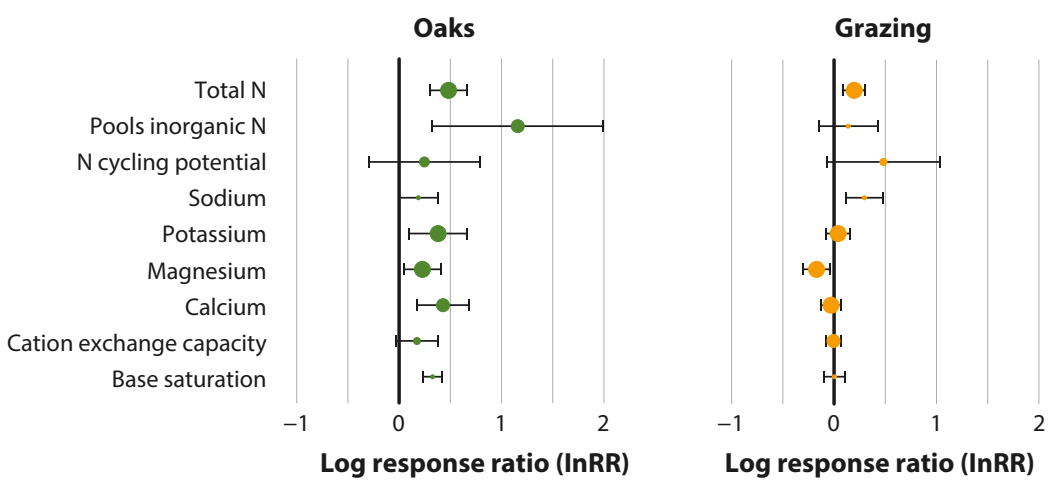

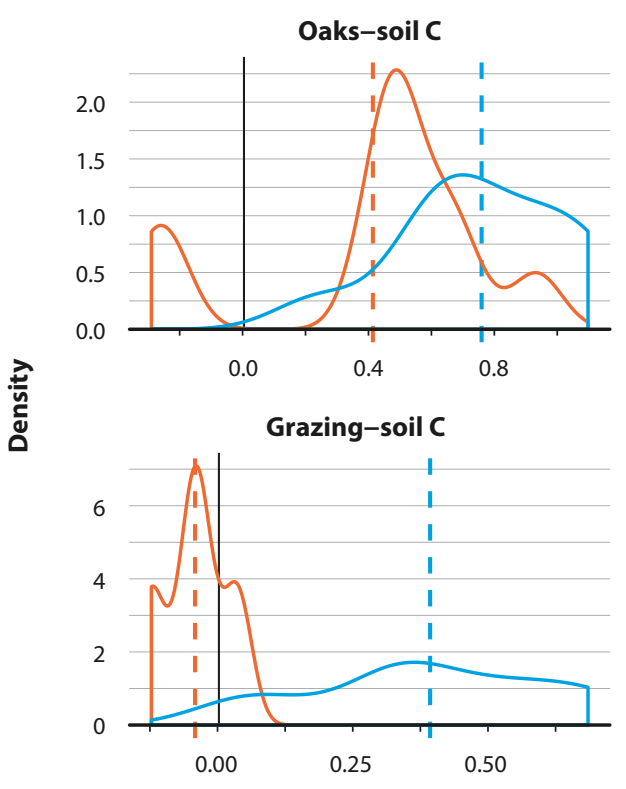
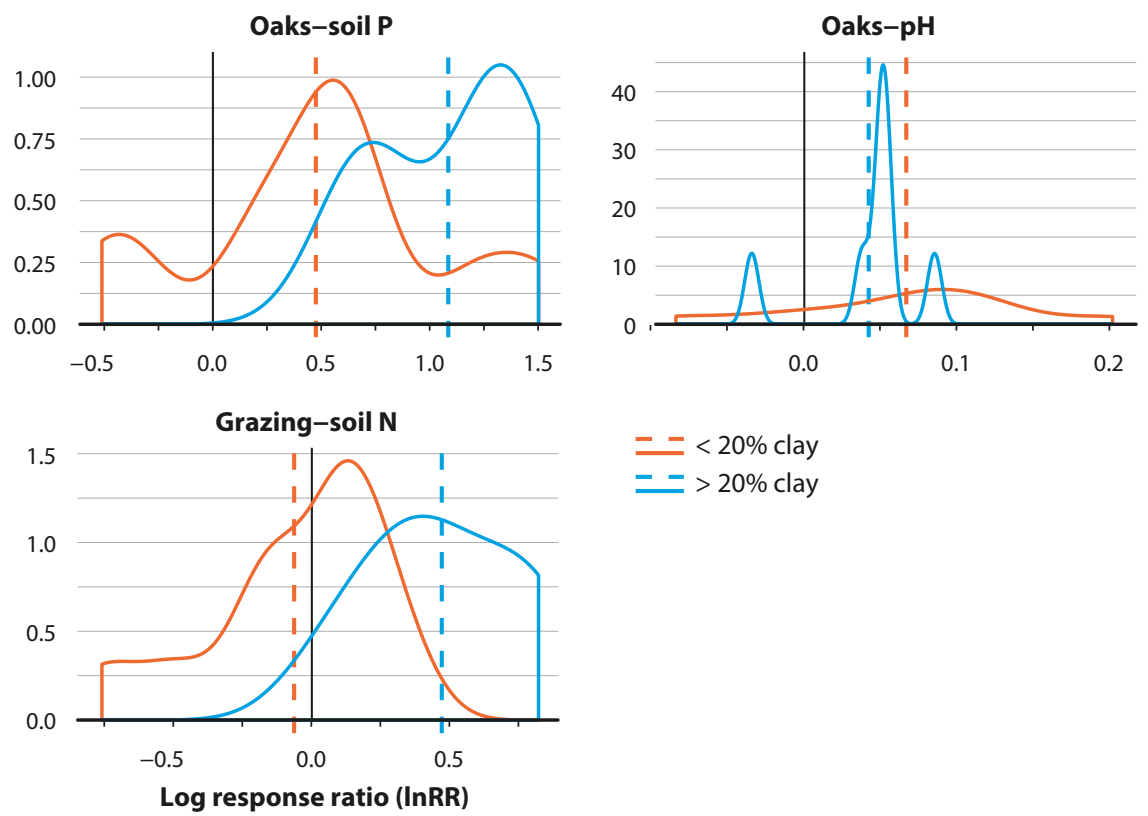

FIG. 5. Density plot displaying significant relationships between oak and grazing response ratios (InRR) and soil texture (percentage clay). Dashed lines = mean response ratio for a given texture category. Nine other management-soil property relationships were assessed and returned nonsignificant results (data not shown). The modulating effects of soil texture were also assessed for oaks on forage, and grazing on plant species richness. Neither relationship was significant (data not shown). Where possible, a similar exercise was performed to assess how aridity moderates management impacts. Aridity was found to only significantly moderate the effects of oaks on soil phosphorus levels and forage production (data not shown). 
al. 2003; Herman et al. 2003). This "island of fertility" effect associated with oaks has been attributed to multiple potentially interacting mechanisms. These include the interception of wet and dry nutrient deposition by oak canopies (Callaway and Nadkarni 1991; Perakis and Kellogg 2007), greater litter inputs beneath oak trees (Dahlgren and Singer 1991; Knops et al. 1996), increased soil faunal activity (Dahlgren et al. 2003), hydraulic lift (Ishikawa and Bledsoe 2000) and increased root interception of nutrients that would otherwise be leached from the system (Perakis and Kellogg 2007).

It is also possible that oak roots relocate nutrients from adjacent open grasslands, concentrating them beneath their canopy - or that livestock elevate soil nutrients as they seek shade beneath these trees. However, both of these mechanisms appear unlikely (Dahlgren et al. 1997; Perakis and Kellogg 2007). Whatever the driving cause, it is clear that oaks create patches of soil fertility associated with increased levels of soil C and microbial biomass across California's rangelands, with possible consequences for public benefits such as climate change mitigation.

The effects of oaks on soil fertility did not seem to translate into similar effects on forage productivity and herbaceous species richness, at least with enough consistency to be significant when summarized across all

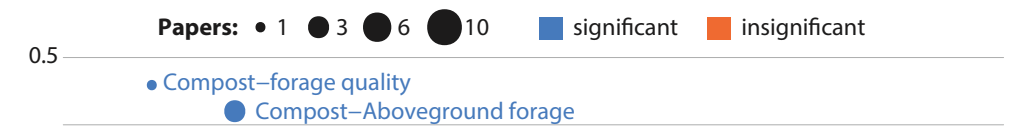

0.4

0.3

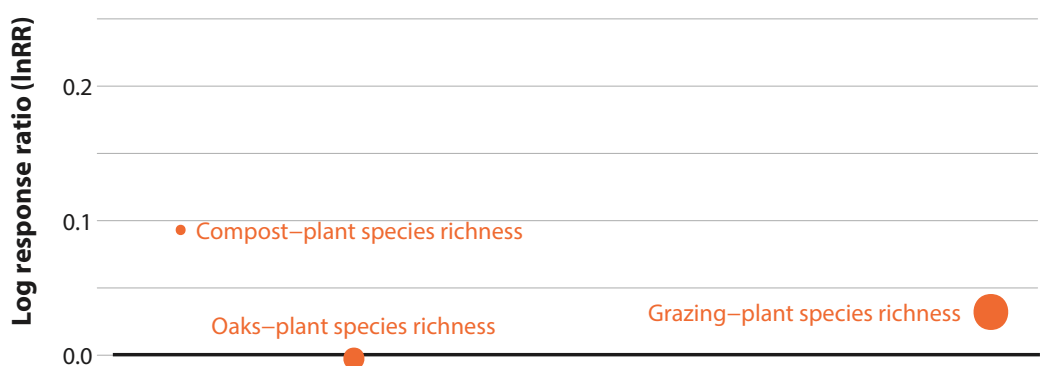

0.0

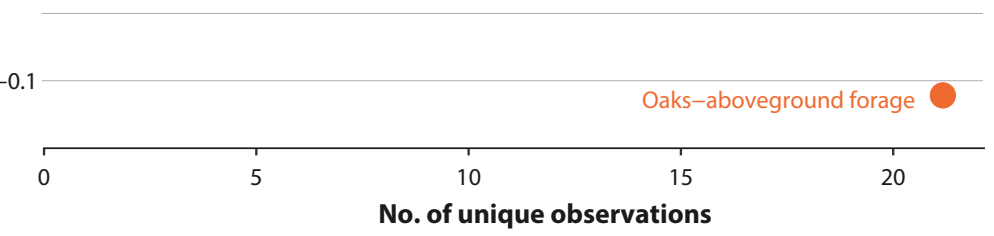

FIG. 6. Mean response ratio (InRR), number of unique observations and significance of management-plant metric relationships. Significant difference between treatment and control for a given soil property is denoted by color, with blue points significant and red points insignificant. The size of each circle is a function of the number of papers supporting that relationship. studies and contexts (fig. 6). In the case of forage production, this is perhaps not surprising since considerable variability exists among individual oak trees, with some trees promoting forage production and others inhibiting it (Callaway et al. 1991).

Prior work has found oak individuals that inhibit understory production typically have shallower root systems, a phenomenon that may be due to any number of environmental or genetic reasons and which results in competition for limiting resources or suppression of herbaceous plant growth by allelopathic chemicals (Callaway et al. 1991; Koteen et al. 2015). At a watershed-scale, forage productivity may also show an inverse relationship with the density of oak trees (Battles et al. 2008). Despite the potential importance of these factors in driving oak-forage productivity relationships across the state, we were unable to account for either in our review. However, we were able to detect a relationship with aridity, with forage production decreasing beneath oak trees in cooler, wetter sites (data not shown).

A number of areas for future work stand out as priorities for this management practice. First, research is needed to quantify rates of change in soil properties with oak establishment, as the literature to date generally focuses on comparing established trees ( $>80$ years old) to adjacent open grasslands. Understanding how quickly and how much each soil property changes after an oak planting will be important for policy and practice, which have expectations on much shorter time scales ( $<5$ years).

At the same time, given the strong and relatively consistent influence of mature oaks on soil properties, priority should be placed on determining how to improve oak regeneration and ensure the success of silvopasture projects presently and in California's future climate (Bernhardt and Swiecki 2015). Finally, because forage dynamics are critical to livestock production systems, future work should continue disentangling patterns in forage productivity and bolstering evidence for oak impacts on forage quality.

\section{Grazing: Soil texture affects response of soil C}

In California's rangelands - which typically receive minimal inputs like irrigation and fertilizer - livestock grazing is the dominant land use and is therefore one of the most readily available management tools for landowners (Huntsinger et al. 2010). The ability of grazing to influence ecosystem outcomes particularly in water-limited systems is an area of active debate (Booker et al. 2013; Sanderson et al. 2020; Stanton et al. 2018; Teague et al. 2013). However, grazing management has been shown through meta-analysis to alter soil properties such as soil C, total $\mathrm{N}$ and bulk density globally (Abdalla et al. 2018; Byrnes et al. 2018) and plant community dynamics regionally (Stahlheber and D’Antonio 2013). 
Unfortunately, although our intent was to assess the effects of different grazing strategies, we were unable to go beyond presence-absence of grazing. Over half of the grazing studies (63\%) reported grazing intensity, and most of these reported grazing during the growing season at low-moderate or moderate intensities.

Observations of extreme grazing intensities (low and heavy) were lacking, as were studies documenting the effects of year-round and dormant-season grazing (table 3). The near absence of these strategies in the literature probably reflects the fact that very little land is managed this way in California (Huntsinger et al. 2007), although management will certainly vary from site to site based on resource needs and management goals, and some regions may rely on year-round grazing more than others (Liffmann et al. 2000).

The relative uniformity of grazing strategies across presence-absence studies, along with the lack of studies that explicitly manipulate and compare deferment and within-season rest and rotation (i.e., compare among "grazing systems"), prevented us from quantitatively assessing the effects of these finer-level, but potentially important, moderators.

Our literature review revealed that the presence of grazing, when pooled across all studies and contexts, significantly influenced a number of soil properties (fig. 3). Specifically, grazed sites had greater soil compaction and considerably more bare ground than ungrazed sites, a pattern that has been shown elsewhere (Augustine et al. 2012; Byrnes et al. 2018), with possible consequences for outcomes such as water infiltration (reduced infiltration) (Savadogo et al. 2007) and grassland breeding bird habitat (increased suitability) (Gennet et al. 2017).

Grazed sites also had higher levels of soil N, driven by a small but significant increase in total $\mathrm{N}$ (fig. 4), and lower levels of exchangeable magnesium (fig. 4) and soil $\mathrm{pH}$ (fig. 3). This collectively indicates that grazing can influence soil fertility across California's landscapes. Increases in soil $\mathrm{N}$ with grazing have been reported in some global reviews (Abdalla et al. 2018) but not others (Byrnes et al. 2018), and without more information we are unable to determine the cause of such an increase in California. However, possible explanations include changes in plant species composition, biomass production and allocation, and spatial redistribution of $\mathrm{N}$ with livestock waste (Piñeiro et al. 2010).

Policymakers are increasingly interested in leveraging grazing management to help sequester carbon and achieve climate change mitigation goals (Byrnes et al. 2017). While evidence is mixed and estimates are highly uncertain, prescribed grazing has been suggested to sequester carbon at rates up to 1.8 metric tons per hectare per year in some mesic regions (Conant and Paustian 2002). Whether the sequestered carbon remains in the ground long enough to help mitigate climate change depends on various aspects of the system, including how protected the carbon is from microbial decomposition (Lavallee et al. 2020).
TABLE 3. Representation of different grazing strategies (intensity, season) in the literature

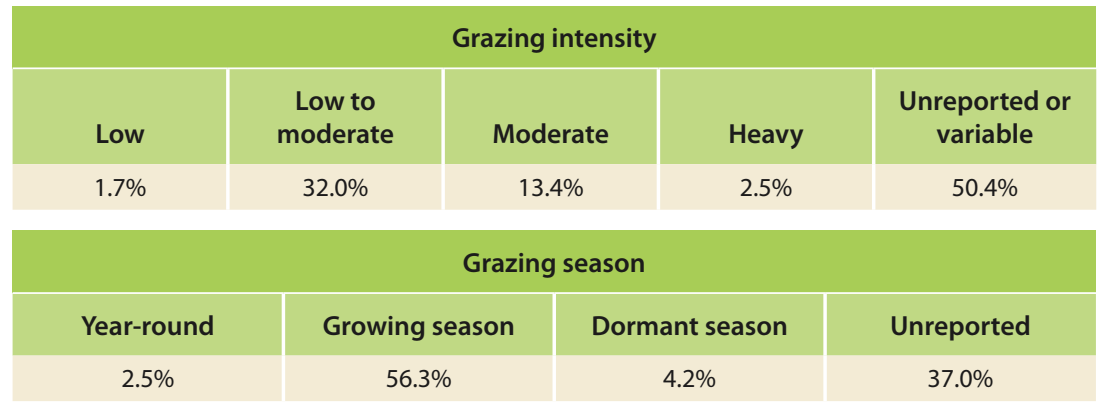

Numbers indicate the percentage of unique observations that comprised each category.

In California, the influence of grazing on soil $\mathrm{C}$ is thought to be small relative to factors such as climate and soil type, with the net effect depending on a number of site-specific conditions such as management history and soil texture (Stanton et al. 2018). Supporting this expectation, and in line with prior work (Silver et al. 2010), we found that across all studies the presence of grazing had no significant effect on soil C.

However, similar to oaks, we found that soil texture significantly modified the effect of grazing, such that grazing had more of a positive effect on soil C in soils with higher clay content (fig. 5). McSherry and Ritchie (2013) report a similar pattern for arid sites in their global meta-analysis. Possibly, sandier soils are more susceptible to $\mathrm{C}$ loss through reductions in vegetation cover and increased wind erosion of fine particles (Steffens et al. 2008). Finer-textured soils also have a greater capacity to stabilize increased inputs of organic material that may occur through compensatory growth of vegetation (Jackson and Bartolome 2007; Singh et al. 2018).

While this result is derived from a relatively small sample size and should therefore be interpreted with caution, it suggests that soils with higher clay content, such as those of the Central Coast and Sacramento Valley, may be more amenable to grazing-induced improvements in soil C - and other measures of soil fertility (fig. 5) - than those with lower clay content, such as soils of the San Joaquin Valley. Future work should focus on understanding whether, and to what degree, this relationship holds true with an expanded data set across the state.

A number of priorities for future grazing research emerged from our review. Specifically, robust long-term and well-replicated experiments are needed to assess how soil properties and plant metrics co-vary in response to grazing strategies across California's diverse rangeland landscapes. These experiments should aim to go beyond presence-absence and begin identifying the impact of strategies such as within-season rest and rotation. Soil properties that may deserve elevated attention include microbial biomass and soil moisture (or other proxies of soil water availability), as these lacked enough evidence to be included in the current 
review and yet are important components of semi-arid Mediterranean-type systems.

Finally, while some work has been done to assess the effects of residual dry matter - a proxy for grazing intensity - on forage productivity (Bartolome et al. 2007), few studies directly compare the effects of grazing strategies on this plant metric; therefore, measurements of forage productivity and quality in response to different grazing strategies are needed.

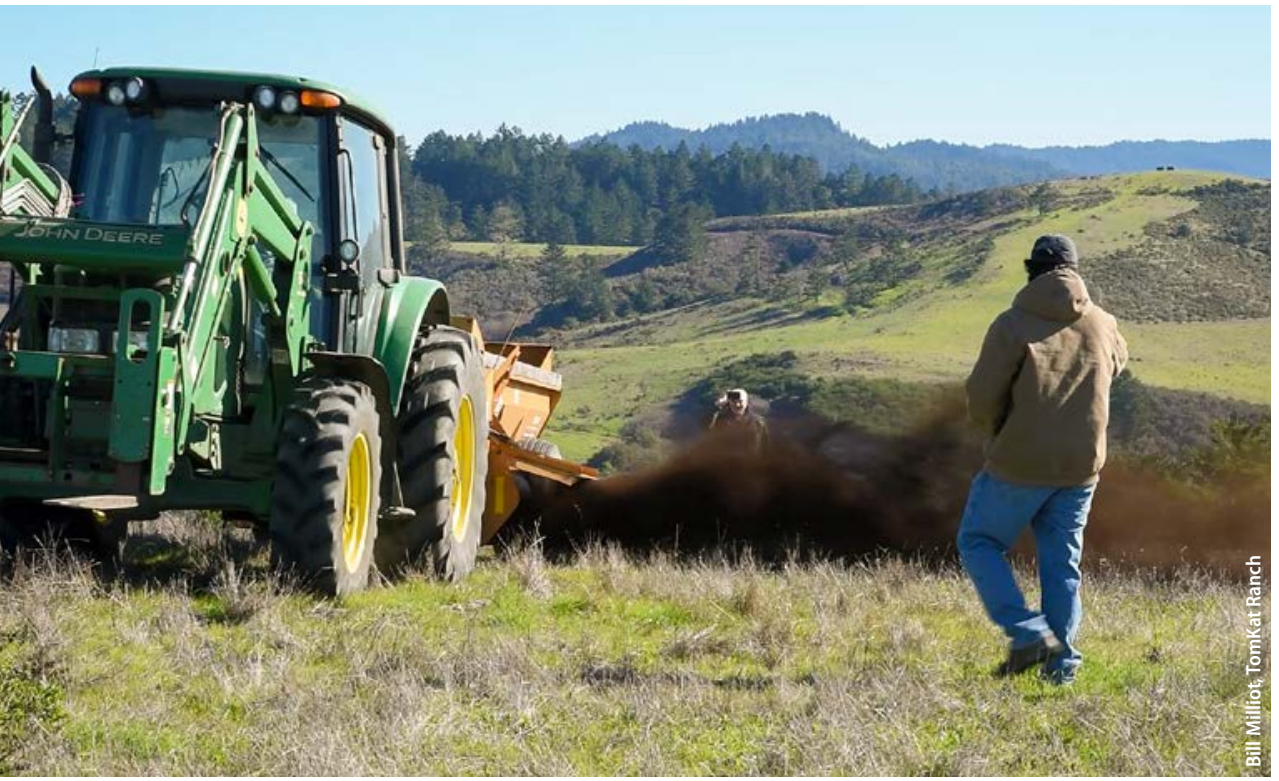

An experimental plot at TomKat Ranch, Pescadero California, receives a onetime compost application as part of a larger statewide NRCS project to evaluate the effects of compost on soil- and plantrelated outcomes.

\section{Compost amendments: Applications increase forage}

Applying composted organic amendments to rangeland soils is a practice increasingly promoted by government and nongovernment agencies across the state. These amendments have been shown to improve on-ranch soil C sequestration and forage quantity and quality at two sites in Northern California (Ryals et al. 2014; Ryals et al. 2016). In addition, a recent global meta-analysis by Gravuer et al. (2019) showed that rangeland forage production and soil $\mathrm{C}$ increase in the first few years following application of organic amendments. However, Gravuer et al. (2019) caution that these benefits may come with trade-offs depending on the type of organic material used and the rates of application.

If the potential on-site ecosystem benefits of compost amendments lead to increased demand for compost across the state, that could drive greater diversion of organic wastes away from traditional fates such as landfills and help to mitigate greenhouse gas emissions downstream as well (DeLonge et al. 2013). For these reasons, expert opinion ranks rangeland compost amendments as one of the most promising ways to help achieve statewide climate change mitigation goals (Stanton et al. 2018), and this practice is currently incentivized through the Healthy Soils Program. The expectation by many, although perhaps not all (Booker et al. 2013), is that these amendments will improve forage dynamics for livestock production systems while simultaneously promoting climate adaptation and resiliency of the state's working landscapes (Flint et al. 2018).

In our review, we were able to assess the effects of compost on soil $\mathrm{C}$ and total soil $\mathrm{N}$, and from two sites we were able to assess plant-related metrics. We found that forage production and quality increased with compost addition (fig. 6) but that soil $\mathrm{C}$ and total soil $\mathrm{N}$ remained unchanged (fig. 3). The lack of significant differences in these soil properties possibly reflects the limited amount of observations derived from within California and also the short duration in which effects have been tracked over time. For example, one of the primary soil $\mathrm{C}$ data sets contributing to our review came from samples collected just 1 year after compost was applied (Silver et al. 2018).

Given more time, changes in soil properties may start to emerge (Gravuer et al. 2019). Indeed, modeling efforts have demonstrated the potential for compost to improve on-site and public ecosystem benefits across California over longer time frames (Flint et al. 2018; Ryals et al. 2015; Silver et al. 2018). However, well-replicated long-term studies are needed to validate those models, improve the evidence base for compost amendments to achieve desired outcomes across California's diverse rangelands, and determine whether the currently limited supply of compost would provide greater benefits in other systems, such as irrigated cropland.

\section{Riparian restoration: Limited published evidence}

Riparian corridors are globally recognized for their potential to provide multiple values and services, including carbon sequestration (Dybala, Matzek, et al. 2019), wildlife habitat (Dybala, Steger, et al. 2019; RHJV 2004) and maintenance of water quality and quantity (Bedard-Haughn et al. 2004; George et al. 2011). In California, where more than $90 \%$ of riparian ecosystems have been lost or degraded (RHJV 2004), state investment in riparian restoration is set to triple by 2030 (CNWL CCIP 2019).

Expectations from both private and public sectors are that riparian restoration will help to recoup lost ecosystem services and build resilience and adaptation into California's landscapes (Jackson et al. 2015; Seavy et al. 2009). However, evidence documenting the benefits of riparian restoration on California rangeland soils and understory vegetation is lacking in the literature (Jackson et al. 2015; Matzek et al. 2018). As a result, we were unable to characterize the influence of rangeland riparian restoration on any of the soil properties or plant metrics in our review.

The few studies that exist present mixed evidence for this practice's influence on ecosystem properties on California rangelands. For example, Lewis et al. (2015) 
demonstrated considerable soil C accrual following a combination of active (e.g., planting) and passive (e.g., grazing removal) restoration of riparian forests in Marin, Napa and Sonoma counties. That pattern has also been recently demonstrated with riparian restoration of agricultural lands in the Central Valley (Dybala, Steger, et al. 2019). Moreover, in rangelands of Marin, Sonoma and Mendocino counties, Gornish et al. (2017) found higher native herbaceous plant richness in actively restored sites than in control sites. In contrast, Briar et al. (2012) found that 3 years of passive restoration had limited effects on soil nematode communities in Yolo County.

Adopting monitoring protocols and performing research to supplement implementation will be critical to help bolster peer-reviewed evidence, constrain estimates on the rate and magnitude of change over time and provide the groundwork for evaluating the effects of this rangeland management practice on soil properties and plant metrics across California.

\section{Three takeaways}

Three general takeaways emerge from our quantitative synthesis of California's literature: (1) rangeland management signals can be observed for some soil and plant-related metrics but not others, suggesting that climate and inherent spatial variability in soil type, topography and land-use history can, but do not always, overwhelm the effects of management on California's rangelands; (2) soil texture moderates how some soil properties respond to management, and so it may be an important contextual variable to consider in modeling activities and land management decisions; (3) levels of in-state evidence that support our understanding of these four management practices vary by metric, but
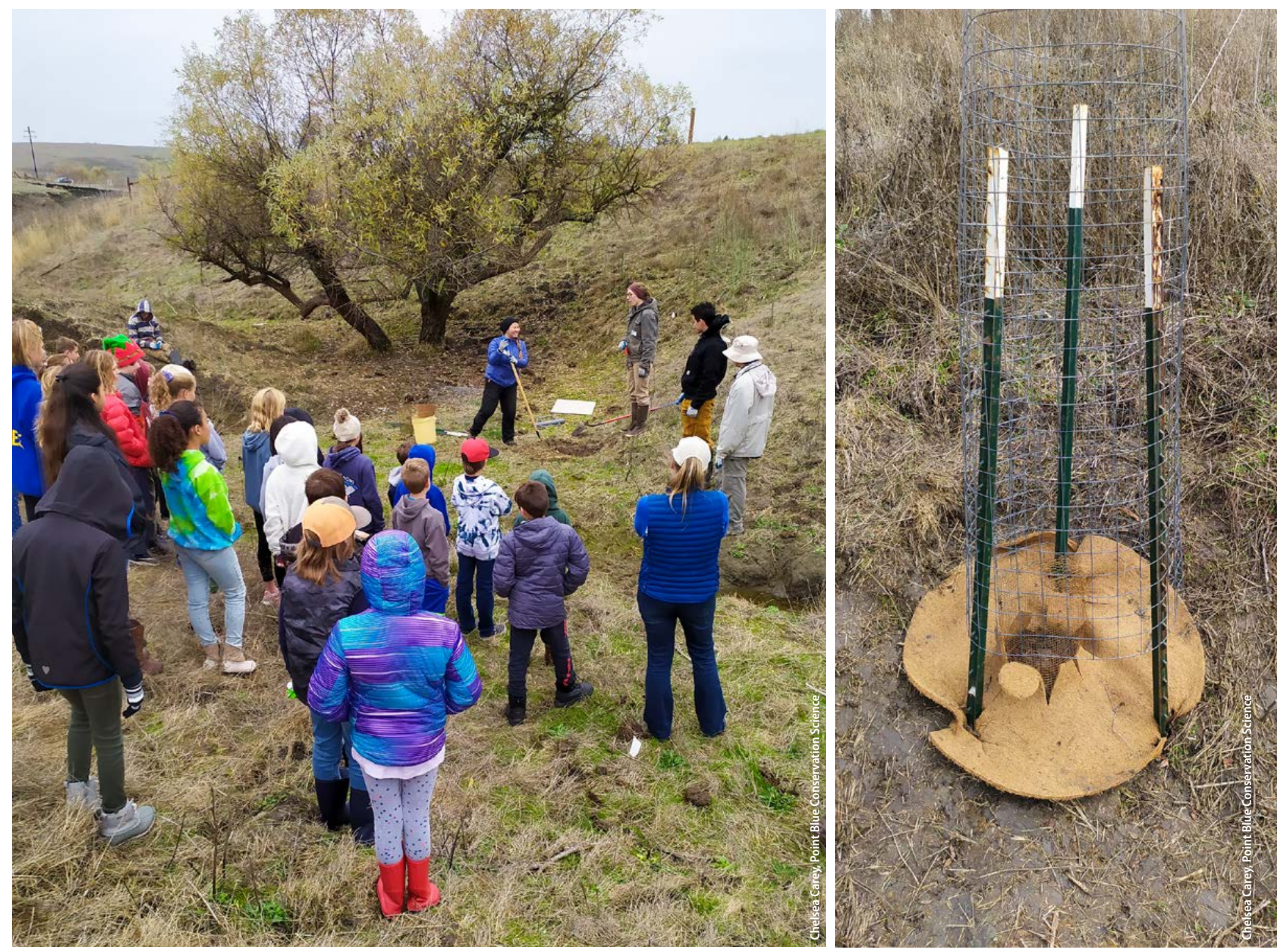

Left, fifth grade students learn how to plant acorns as part of a riparian restoration project in Sonoma County, California. Right, coast live oak acorns are protected from herbivory after planting in Sonoma County. 
overall fall in this descending order: oaks > grazing > compost amendments $>$ riparian restoration.

Continued support for research on these management practices will help to inform recommendations and adoption at scale. Predicting the effects of each management approach could further be supported by the refinement of organizing frameworks such as ecological site descriptions and state-and-transition models (Jackson and Bartolome 2002; Ratcliff et al. 2018), which are currently less developed for California than other Western states. In addition to more traditional research approaches, demonstration projects supported through the Healthy Soils Program offer one promising avenue to gain additional data, as does monitoring associated with state-funded projects through the California 2030 Natural and Working Lands Climate Change Implementation Plan. CA
C.J. Carey is Working Lands Research Director and Principal Soil Ecologist, Point Blue Conservation Science; K. Gravuer is NatureNet Science Fellow, Arizona State University and The Nature Conservancy; S. Gennet is Director, North America Sustainable Grazing Lands, The Nature Conservancy; D. Osleger is Research Assistant, National Center for Ecological Analysis and Synthesis; and S.A. Wood is Senior Scientist, Agriculture and Food Systems, The Nature Conservancy, and Associate Research Scientist, School of Forestry and Environmental Studies, Yale University.

This project was completed as part of the Science for Nature and People Partnership (SNAPP) working group on "Managing Soil Carbon". We thank participants of the working group for their support and thoughtful feedback during the development of this project. We also thank Nat Seavy, Grant Ballard, Kevin Watt and four anonymous reviewers for providing helpful comments on earlier drafts of this manuscript. Funding for C.J. Carey was provided by TomKat Ranch.

\section{References}

Abdalla M, Hastings A, Chadwick DR, et al. 2018. Critical review of the impacts of grazing intensity on soil organic carbon storage and other soil quality indicators in extensively managed grasslands. Agr Ecosyst Environ 253:62-81. doi:10.1016/j agee.2017.10.023

Allen-Diaz B, Jackson RD. 2005. Herbaceous Responses to Livestock Grazing in Californian Oak Woodlands: A Review for Habitat Improvement and Conservation Potential. USDA Forest Service Gen Tech Rep, PSW-GTR-195.

Augustine DJ, Booth DT, Cox SE, et al. 2012. Grazing intensity and spatial heterogeneity in bare soil in a grazing-resistant grassland. Rangeland Ecol Manag 65:39-46. doi:10.2111/ REM-D-11-00005.1

Bartolome JW, Jackson RD, Betts ADK, et al. 2007. Effects of residual dry matter on net primary production and plant functiona groups in Californian annual grasslands. Grass Forage Sci 62:445-52. doi:10.1111/j.13652494.2007.00599.x

Battles JJ, Jackson RD, Shlisky A, et al. 2008. Net Primary Production and Biomass Distribution in the Blue Oak Savanna. USDA Forest Service Gen Tech Rep, PSW-GTR-217.

Bedard-Haughn A, Tate KW, van Kessel C. 2004. Using nitrogen-15 to quantify vegetative buffer effectiveness for sequestering nitrogen in runoff. J Environ Qual 33:2252-62. doi:10.2134/jeq2004.2252 Bernhardt E, Swiecki TJ. 2015 Long-term performance of minimum-input oak restoration plantings. USDA Forest Service Gen Tech Rep, PSW-GTR-251:10.
Booker K, Huntsinger L, Bartolome JW, et al. 2013. What can ecological science tell us about opportunities for carbon sequestration on arid rangelands in the United States? Global Environ Chang 23:240-51. doi:10.1016/j.gloenvcha.2012.10.001

Boyd CS, Svejcar TJ. 2009. Managing complex problems in rangeland ecosystems. Rangeland Ecol Manag 62:491-9. doi:10.2111/08-194.1

Bradford MA, Carey CJ, Atwood $\mathrm{L}$, et al. 2019. Soil carbon science for policy and practice. Nature Sustainability 2:1070-2. doi:10.1038/s41893-019-0431-y

Briar SS, Culman SW, YoungMathews A, et al. 2012. Nematode community responses to a moisture gradient and grazing along a restored riparian corridor. Eur J Soil Biol 50:32-8. doi:10.1016/j.ejsobi.2011.11.006 Byrd KB, Flint LE, Alvarez $\mathrm{P}$, et al. 2015. Integrated climate and land use change scenarios for California rangeland ecosystem services: Wildlife habitat, soil carbon, and water supply. Landscape Ecol 30:729-50. doi:10.1007/s10980-015-0159-7

Byrnes RC, Eastburn DJ, Tate KW, et al. 2018. A global metaanalysis of grazing impacts on soil health indicators. J Environ Qual 47:758-65. doi:10.2134/ jeq2017.08.0313

Byrnes R, Eviner V, Kebreab E, et al. 2017. Review of research to inform California's climate scoping plan: Agriculture and working lands. Calif Agr 71:160-8. doi:10.3733/ca.2017a0031
Callaway RM, Nadkarni NM. 1991. Seasonal patterns of nutrient deposition in a Quercus douglasii woodland in central California. Plant Soil 137:209-22 doi:10.1007/BF00011199

Callaway RM, Nadkarni NM, Mahall BE. 1991. Facilitation and interference of Quercus douglasii on understory productivity in central California. Ecology 72:1484-99. doi:10.2307/1941122

Cameron DR, Marty J, Holland RF. 2014. Whither the rangeland?: Protection and conversion in California's rangeland ecosystems. PLOS ONE 9:e103468. doi:10.1371/journal. pone.0103468

[CDFA] California Department of Food and Agriculture. 2018 California Agricultural Statistics Review. www.cdfa.ca.gov.

Chaplin-Kramer R, Tuxen-Bettman K, Kremen C. 2011. Value of wildland habitat for supplying pollination services to California agriculture. Rangelands 33:33-42. doi:10.2111/1551501X-33.3.33

[CNWL CCIP]. 2019. California 2030 Natural and Working Lands Climate Change Implementation Plan. California Air Resources Board, California Environmental Protection Agency, California Department of Food and Agriculture, and California Natural Resources Agency. https://ww3.arb.ca.gov/cc/ natandworkinglands/draft-nwlip-1.3.19.pdf

Conant RT, Paustian K. 2002 Potential soil carbon sequestration in overgrazed grassland systems. Globa Biogeochem Cy 16:90-1-90-9. doi:10.1029/2001GB001661
Dahlgren R, Horwath W, Tate KW, et al. 2003. Blue oak enhance soil quality in California oak woodlands. Calif Agr 57:427. doi:10.3733/ca.v057n02p42 Dahlgren R, Singer M. 1991. Nutrient Cycling in Managed and Unmanaged Oak WoodlandGrass Ecosystems. USDA Forest Service Gen Tech Rep, PSW-126. Dahlgren RA, Singer MJ, Huang X. 1997. Oak tree and grazing impacts on soil properties and nutrients in a California oak woodland. Biogeochemistry 39:45-64. doi:10.1023/A:1005812621312

Dass $P$, Houlton BZ, Wang Y, et al. 2018. Grasslands may be more reliable carbon sinks than forests in California Environ Res Lett 13:074027. doi:10.1088/1748-9326/aacb39 DeLonge M, Ryals R, Silver W. 2013. A lifecycle model to evaluate carbon sequestration potential and greenhouse gas dynamics of managed grass lands. Ecosystems 16:962-79. doi:10.1007/s10021-013-9660-5

Derner JD, Stanley C, Ellis C. 2016. Usable science: Soil health. Rangelands 38:64-7. doi:10.1016/j.rala.2015.10.010

Derner JD, Smart AJ, Toombs TP, et al. 2018. Soil health as a transformational change agent for US grazing lands management. Rangeland Ecol Manag 71:403-8. doi:10.1016/ rama.2018.03.00

Dybala KE, MatzekV, Gardali T, et al. 2019. Carbon sequestration in riparian forests: A globa synthesis and meta-analysis. Global Change Biol 25:57-67. doi:10.1111/gcb.14475
Dybala KE, Steger K, Walsh RG, et al. 2019. Optimizing carbon storage and biodiversity cobenefits in reforested riparian zones. J Appl Ecol 56:343-53. doi:10.1111/1365-2664.13272

Ferranto S, Huntsinger L, Kelly M. 2014. Sustaining ecosystem services from private lands in California: The role of the land owner. Rangelands 36:44-51. doi:10.2111/RANGELANDSD-14-00023.1

Flint LE, Flint AL, Stern MA, et al. 2018. Increasing Soil Organic Carbon to Mitigate Greenhouse Gases and Increase Climate Resiliency for California. California's Fourth Climate Change Assessment, California Natural Resources Agency. Pub no. CCCA4-CNRA-2018-006

[FRAP] CAL FIRE Fire and Resource Assessment Program. 2018. California's Forests and Rangelands 2017 Assessment. https://frap.fire.ca.gov/assessment/

Gennet S, Spotswood E, Hammond M, et al. 2017. Livestock grazing supports native plants and songbirds in a California annual grassland. PLOS ONE 12. doi:10.1371/journal. pone.0176367

George MR, Jackson RD, Boyd CS, et al. 2011. A scientific assessment of the effectiveness of riparian management practices. In Conservation Benefits of Rangeland Practices: Assess ment, Recommendations, and Knowledge Gaps. Briske DD (ed.). Washington, DC: USDA-NRCS. p 213-52. 
Gornish ES, Lennox MS, Lewis D, et al. 2017. Comparing herbaceous plant communities in active and passive riparian restoration. PLOS ONE 12. doi:10.1371/journal. pone.0176338

Graham RC, O'Geen TA. 2016. Geomorphology and soils. In Ecosystems of California. Mooney H, Zavaleta E (eds.). Berkeley, CA: UC Press. p 47-73.

Gravuer K, Gennet S, Throop HL. 2019. Organic amendment additions to rangelands: A metaanalysis of multiple ecosystem outcomes. Global Change Biol 25:1152-70. doi:10.1111/ gcb.14535

Hedges LV, Gurevitch J, Curtis PS. 1999. The meta-analysis of response ratios in ex-

perimental ecology. Ecology 80:1150-6. doi:10.1890/00129658(1999)080[1150:TMAORR ]2.0.CO;2

Herman DJ, Halverson LJ, Fireston MK. 2003. Nitrogen dynamics in an annual grassland: oak canopy, climate, and microbial population effects. Ecol Appl 13:593-604 doi:10.1890/1051 0761(2003)013[0593:NDIAAG] 2.0.CO;2

Hruska T, Huntsinger L, Brunson M, et al. 2017. Rangelands as Social-Ecological Systems. In: Briske DD (ed.). Rangeland Systems: Processes, Management and Challenges. Springer Series on Environmental Management. Cham, Switzerland: Springer International Publishing. p 263-302.

Huntsinger L, Bartolome JW, D'Antonio CM. 2007. Grazing management on California's Mediterranean grasslands. In: Stromberg MR, Corbin JD, D'Antonio CM (eds.). California Grasslands: Ecology and Management. Berkeley, CA: University of California Press. p 233-53.

Huntsinger L, Fortmann LP. 1990. California's privately owned oak woodlands: owners, use, and management. Rangeland Ecol Manag 43:147-52.

Huntsinger L, Johnson M, Stafford M, et al. 2010. Hardwood rangeland landowners in California from 1985 to 2004: production, ecosystem services, and permanence. Rangeland Ecol Manag 63:324-34. doi:10.2111/08-166.1

Ishikawa CM, Bledsoe CS. 2000 Seasonal and diurnal patterns of soil water potential in the rhizosphere of blue oaks: evidence for hydraulic lift. Oecologia 125:459-65. doi:10.1007/ s004420000470
Jackson RD, Bartolome JW. 2002. A state-transition approach to understanding nonequilibrium plant community dynamics in California grasslands. Plant Ecol 162:49-65. doi:10.1023/A:1020363603900

Jackson RD, Bartolome JW. 2007. Grazing ecology of California grasslands. In: Stromberg MR, Corbin JD, D'Antonio CM (eds.). California Grasslands: Ecology and Management. Berkeley, CA: University of California Press. p 197-206.

Jackson L, Hodson A, Fyhrie K, et al. 2015. Creekside Plantings and Restoration in California Rangelands, UC Davis Department of Land, Air and Water Resources.

Jose S, Dollinger J. 2019. Silvopasture: a sustainable livestock production system. Agroforest Syst 93:1-9. doi:10.1007/s10457019-00366-8

Knops JMH, Nash TH,

Schlesinger WH. 1996. The Influence of epiphytic lichens on the nutrient cycling of an oak woodland. Ecol Monogr 66:159-79. doi:10.2307/2963473

Koteen LE, Raz-Yaseef N, Baldocchi DD. 2015. Spatial heterogeneity of fine root biomass and soil carbon in a California oak savanna illuminates plant functional strategy across periods of high and low resource supply. Ecohydrol 8:294-308. doi:10.1002/eco.1508

Lavallee JM, Soong JL, Cotrufo MF. 2020. Conceptualizing soil organic matter into particulate and mineral-associated forms to address global change in the 21 st century. Glob Change Biol 26:261-73. doi:10.1111/ gcb.14859

Lewis D, Lennoz M, O'Geen A, et al. 2015. Creek carbon: Mitigating Greenhouse Gas Emissions through Riparian Revegetation, Novato, California: University of California Cooperative Extension in Marin County.

Liffmann RH, Huntsinger L, Forero LC. 2000. To ranch or not to ranch: home on the urban range? J Range Manage 53:362-70.

Matzek V, Stella J, Ropion P. 2018. Development of a carbon calculator tool for riparian forest restoration. Appl Veg Sci 21:584-94. doi:10.1111/ avsc. 12400

McSherry ME, Ritchie ME. 2013 Effects of grazing on grassland soil carbon: a global review. Glob Change Biol 19:1347-57. doi:10.1111/gcb.12144

Myers N, Mittermeier RA, Mittermeier CG, et al. 2000. Biodiversity hotspots for conservation priorities. Nature 403:853-8. doi:10.1038/35002501
Perakis SS, Kellogg CH. 2007. Imprint of oaks on nitrogen availability and $\delta 15 \mathrm{~N}$ in California grassland-savanna: a case of enhanced $\mathrm{N}$ inputs? Plant Ecol 191:209-20. doi:10.1007/ 11258-006-9238-9

Piñeiro G, Paruelo JM, Oesterheld M, et al. 2010. Pathways of grazing effects on soil organic carbon and nitrogen. Rangeland Ecol Manag 63:109-19. doi:10.2111/08-255.1

Plieninger T, Ferranto S, Huntsinger L, et al. 2012. Appreciation, use, and management of biodiversity and ecosystem services in California's working landscapes. Environ Manage 50:427-40. doi:10.1007/s00267012-9900-z

Ratcliff F, Bartolome J, Macaulay L, et al. 2018. Applying ecological site concepts and state-and-transition models to a grazed riparian rangeland. Ecol Evol 8:4907-18. doi:10.1002/ ece3.4057

[RHJV] Riparian Habitat Joint Venture. 2004. Version 2.0. The riparian bird conservation plan: $A$ strategy for reversing the decline of riparian associated birds in California, Stinson Beach, CA: California Partners in Flight.

Roche LM, Schohr TK, Derner JD, et al. 2015. Sustaining working rangelands: Insights from rancher decision making. Rangeland Ecol Manag 68:383-9. doi:10.1016/j. rama.2015.07.006

Ryals R, Eviner VT, Stein C, et al. 2016. Grassland compost amendments increase plant production without changing plant communities. Ecosphere 7. doi:10.1002/ecs 2.1270

Ryals R, Hartman MD, Parton WJ, et al. 2015. Long-term climate change mitigation potential with organic matter management on grasslands. Ecol Appl 25:531-45. doi:10.1890/132126.1

Ryals R, Kaiser M, Torn MS, et al. 2014. Impacts of organic matter amendments on carbon and nitrogen dynamics in grassand soils. Soil Biol Biochem 68:52-61. doi:10.1016/j.soilbio.2013.09.011

Sanderson JS, Beutler C, Brown JR, et al. 2020. Cattle, conservation, and carbon in the western Great Plains. J Soil Water Conserv 75:5A-12A. doi:10.2489/ jswc.75.1.5A

Savadogo P, Sawadogo L, Tiveau D. 2007. Effects of grazing intensity and prescribed fire on soil physical and hydrologica properties and pasture yield in the savanna woodlands of Burkina Faso. Agr Ecosyst Environ 118:80-92. doi:10.1016/j. agee.2006.05.002

Sayre NF, deBuys W, Bestelmeyer BT, et al. 2012. "The range problem" After a century of rangeland science: New research themes for altered landscapes. Rangeland Ecol Manag 65:545-52 doi:10.21111/REMD-11-00113.1

Seavy NE, Gardali T, Golet GH, et al. 2009. Why Climate Change Makes Riparian Restoration

More Important than Ever: Recommendations for Practice and Research. Ecological Rest 27:330-8. doi:10.3368/ er.27.3.330

Shackelford GE, Kelsey R, Sutherland WJ, et al. 2019. Evidence synthesis as the basis for decision analysis: A method for selecting the best agricultural practices for multiple ecosystem services. Front Sustainable Food Syst 3:83. doi:10.3389/ fsufs.2019.00083

Silver WL, Ryals R, Eviner V. 2010.

Soil Carbon Pools in California's Annual Grassland Ecosystems. Rangeland Ecol Manag 63:128-36. doi:102111/REMD-09-00106.1

Silver WL, Vergara SE, Mayer A. 2018. Carbon sequestration and greenhouse gas mitigation potential of composting and soil amendments on California's rangelands, California's Fourth Climate Change Assessment,

California Natural Resources Agency. Publication number: CCCA4-CNRA-2018-002

Singh BP, Setia R, Wiesmeier M, et al. 2018. Agricultural Management Practices and Soil Organic Carbon Storage. In Soil Carbon Storage. Singh BK (ed.). Academic Press, p 207-44.

Stahlheber KA, D'Antonio CM. 2013. Using livestock to manage plant composition: A meta-analysis of grazing in California Mediterranean grasslands. Biol Conservation 157:300-8. doi:10.1016/j.biocon.2012.09.008

Stanton CY, Mach KJ, Turner PA, et al. 2018. Managing cropland and rangeland for climate mitigation: an expert elicitation on soil carbon in California. Climatic Change 147:633-46. doi:10.1007/s10584-018-2142-1

Steffens M, Kölbl A, Totsche

KU, et al. 2008. Grazing effects on soil chemical and physical properties in a 